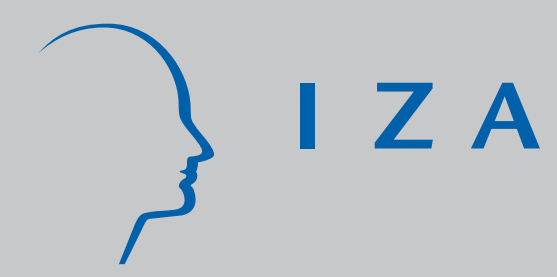

IZA DP No. 185

The Post-Unification German Labor Market

Holger Bonin

Klaus F. Zimmermann

August 2000 


\title{
The Post-Unification German Labor Market
}

\author{
Holger Bonin \\ IZA, Bonn \\ Klaus F. Zimmermann \\ Bonn University, DIW, Berlin, CEPR, London and IZA, Bonn \\ Discussion Paper No. 185 \\ August 2000 \\ IZA \\ P.O. Box 7240 \\ D-53072 Bonn \\ Germany \\ Tel.: +49-228-3894-0 \\ Fax: +49-228-3894-210 \\ Email: iza@iza.org
}

This Discussion Paper is issued within the framework of IZA's research area Labor Markets in Transition. Any opinions expressed here are those of the author(s) and not those of the institute. Research disseminated by IZA may include views on policy, but the institute itself takes no institutional policy positions.

The Institute for the Study of Labor (IZA) in Bonn is a local and virtual international research center and a place of communication between science, politics and business. IZA is an independent, nonprofit limited liability company (Gesellschaft mit beschränkter Haftung) supported by the Deutsche Post AG. The center is associated with the University of Bonn and offers a stimulating research environment through its research networks, research support, and visitors and doctoral programs. IZA engages in (i) original and internationally competitive research in all fields of labor economics, (ii) development of policy concepts, and (iii) dissemination of research results and concepts to the interested public. The current research program deals with (1) mobility and flexibility of labor markets, (2) internationalization of labor markets and European integration, (3) the welfare state and labor markets, (4) labor markets in transition, (5) the future of work, (6) project evaluation and (7) general labor economics.

IZA Discussion Papers often represent preliminary work and are circulated to encourage discussion. Citation of such a paper should account for its provisional character. 
IZA Discussion Paper No. 185

August 2000

\section{ABSTRACT \\ The Post-Unification German Labor Market}

This study surveys the development of the East German labor market after the unification of Germany. We explain that in the last decade, East Germans were faced with very high levels of joblessness that considering labor market exits and active labor market policy, are only partly reported as unemployment. A review of the evidence on the effectiveness of labor market policies suggests that job creation and training programs did not substantially promote reemployment, though they may have alleviated social burdens from unemployment. Discussing what causes the high unemployment in the east, we claim that effects of wage policy have been overrated. Differences in unemployment rates are also the result of more ample labor supply. We show that employment levels in the east have almost converged on western standards. The structure of employment, however, differs. Shortage of part-time work, service jobs and independent employment indicates that East Germany has failed to develop a service economy. We argue that unqualified adaptation to western procedures aggravated the investment and employment problem in the east.

JEL Classification: J40, O50, P27

Keywords: East Germany, unemployment, transitional economies

Klaus F. Zimmermann

IZA

P.O. Box 7240

D-53072 Bonn

Germany

Tel.: +49-228-3894-201

Fax: +49-228-3894-210

Email: Zimmermann@iza.org 


\section{Introduction}

Even a decade after the unification of the two German states, Germany is struggling with the integration of the former eastern command economy into the West German social market-led economy. As the economic catching up process slowed down in recent years, expectations that the economic transformation could be completed fast and smoothly, fuelled by many political leaders, were disproved as overly optimistic. Instead, the impression is rising that it will still take a considerable amount of time until the East German states will become the flourishing landscapes (blühende Landschaften) once promised by the former German chancellor Helmut Kohl.

The Economic, Monetary and Social Union between East and West Germany, which was established on July 1, 1990, uncovered the structural weaknesses of the run-down East German economy. The sudden exposure to competition from West Germany and from abroad, together with a breakdown of traditional export markets, destroyed the economic viability of large parts of the East German capital stock and caused an unprecedented increase in effective unemployment. Immediately after unification, a complete collapse of productivity and employment in East Germany was avoided only with substantial financial transfers from the West.

The deep recession during the first year after the economic union was succeeded by a period of continuous economic growth, which started, however, from a very low level of economic activity. In 1991, GDP per capita in East Germany amounted to less than one third of the western level. Restructuring and privatization of the East German economy, which were fostered through massive investment incentives, and the renewal of public infrastructure initially supported rapid economic expansion. Until 1994, annual growth rates in East Germany reached up to 10 percent.

Since then, economic progress has turned much less substantial. In recent years, annual growth merely ranged between 2 and 3 percent. The catching up of the eastern economy, it seems, has come almost to a standstill. Although the eastern capital stock improved significantly, productivity has not reached up to two thirds of the western level. Private absorption, which is financed through public transfers to a large extent, continues to exceed domestic 
product by about one third, imposing sizeable pressure on government budgets.

One of the most striking features of the eastern economy after ten years of unification is the persistence of very high levels of unemployment. The restructuring and modernization of the East German command economy had a dramatic impact on employment and labor utilization. Since unification, the number of regularly employed in East Germany declined by almost 40 percent. By the end of 1999, registered unemployment was still exceeding 19 percent of the labor force, compared to a rate of less than 10 percent in the West German states. Considered the rather poor recent performance of the eastern economy, a significant employment upswing seems unlikely in the medium-term future.

The issues to be discussed are what caused the emergence and persistence of unemployment in East Germany, and whether there are promising policy instruments to reduce what appears to many as an intolerably high number of displaced workers. This paper contributes to these issues by monitoring the development of the East German labor market after unification. Section 2 summarizes the main trends in both unemployment and employment in East Germany during the past decade, and describes how labor market policy responded to emerging unemployment. Section 3 surveys the available evidence regarding the success of active labor market policies. Section 4 explores to what extent the adjustment process in the East to West German standards is completed. To conclude, Section 5 debates whether labor market convergence is really an adequate goal for East Germany.

\section{The East German Labor Market Since Unification}

The process of transforming the eastern command economy necessarily affected the level of employment negatively. The artificial full employment policy of the GDR that gave a constitutional right to work and employment made state-owned companies and public administration overstaffed, compared to western standards. The monetary union at parity forced the eastern economy into competition with the world market at a high real exchange rate, which according to one early estimate (Akerlof et al. (1991)) 
left only 8 percent of the East German workforce employed in enterprises whose revenue was able to cover operating costs.

Figure 1 Official German Unemployment Rates, Period 1991- 1999

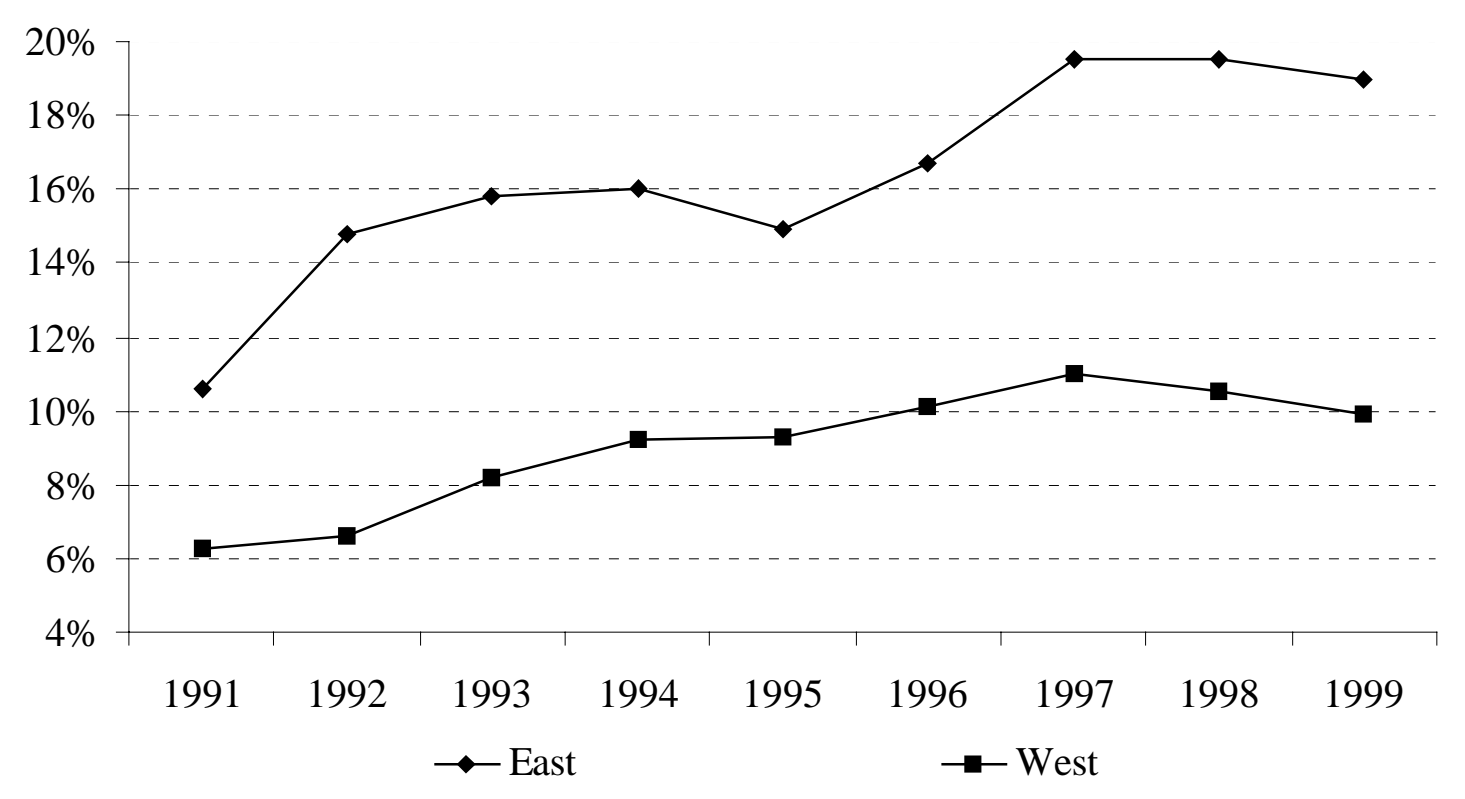

Sources: Sachverständigenrat, Yearly Report, various issues; German Statistical Yearbook, various issues.

Due to the serious shortage of economically viable jobs, unemployment in East Germany increased sharply in the first two years after unification. The number of registered unemployed was rising from 83 thousand in the second quarter of 1990 to almost 1.2 million persons in 1992. As is displayed in Figure 1, the official unemployment rate (based on the civil dependent labor force), reporting 1.1 percent before economic unification, soon approached 15 percent.

During the period from 1992 to 1994, as the eastern economy entered into the recovery phase of the output J-curve, the contraction of employment slowed down. By the year 1995, the number of registered unemployed declined to about 1 million persons. However, when the German economy as a whole entered into a recession, the unemployment rate in the East, following the West German pattern, rose further to 19.5 percent in 1997.

The recent economic upswing, which brought down the West German unemployment rate below the mark of 10 percent, has not significantly relieved the eastern labor market so far: The ongoing rectification of 
structural distortions due to the transformation process, notably the contraction of an inflated construction sector, is reducing employment opportunities further (Brenke/Schmidt (1999)). In 2000, the number of registered unemployed is likely to persist above 1.3 million, which is about 19 percent of the labor force.

Inspection of officially published unemployment figures only vaguely covers the actual size of the employment problem in East Germany. As a reaction to the unparalleled level of worker displacement, government authorities established extensive work creation measures. Figure 2 gives an impression of the number of effective unemployed who are hidden through labor market policies.

In the last quarter of 1991 when the employment crisis reached its peak about 2.4 million persons were effectively without employment. At that time, almost 30 percent of the eastern labor force was registered unemployed, engaged in short-time work or in training and employment creation programs. ${ }^{1}$ This rate fell to 22.3 percent due to the recovery of production during the period between 1992 and 1995. Since then, however, the real level of unemployment in East Germany has been increasing again and approached 1.9 million persons by the end of 1999. Thus effective joblessness is still more than 40 percent higher than registered unemployment.

This calculation of effective unemployment ignores east-west labor migration and commuters. Seeking employment in the West was a frequent response to the economic uncertainties and worsening eastern labor market conditions in the aftermath of unification (Wagner (1992)). In fact, there was a widespread fear that East Germans immigrating westward could overflood their West German countrymen, which enforced rapid economic integration of East Germany. Between 1989 and 1991, 400,000 East Germans (net) of working age migrated to the West. An additional 200,000 employable persons had left the East German states by the end of 1994 when net migration between East and West turned almost into balance.

1 The full-time equivalent of short-time work is calculated using information on the distribution of actual hours worked. Participation in training programs does not necessarily cover full-time education. As a consequence, the figure may overstate the level of hidden unemployment. 
Figure 2 The Structure of Unemployment in East Germany, Period 1991 - 1999

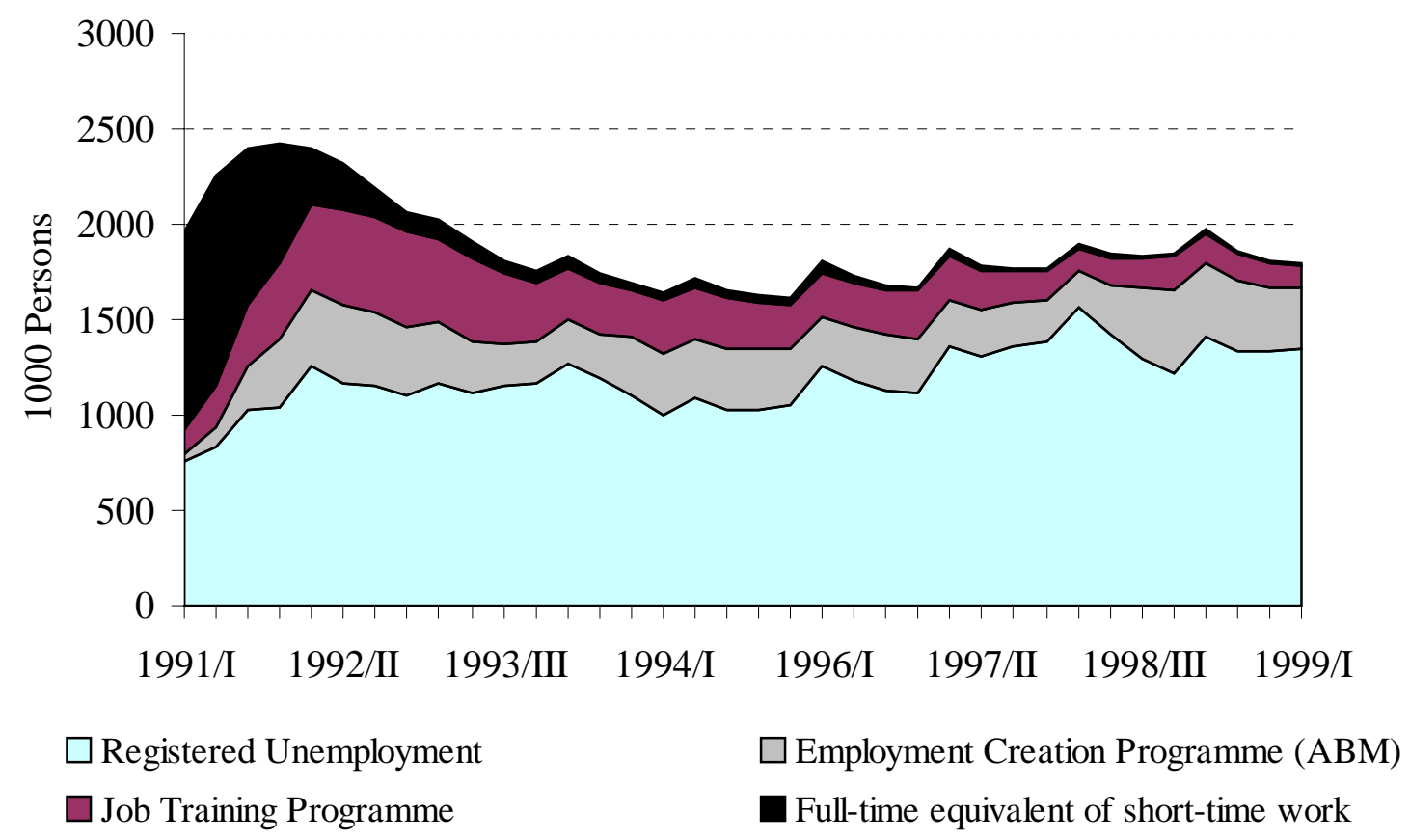

Source: Sachverständigenrat, Yearly Report, various issues.

Moreover, a considerable number of East Germans is prepared to travel long distances to avoid unemployment. Already in 1991, about 290,000 workers (net) were commuting to the West. The number of commuters rose further to more than 350,000 when unemployment peaked in 1992 and since then has only gradually declined. Commuting and out-migration hence reduce current labor supply in East Germany by about 1 million persons. Had commuters and labor emigrants stayed in the eastern labor market, it seems not unlikely that an equivalent size of workers would have been unemployed additionally. Re-evaluating effective joblessness on the base of this argument, the real East German unemployment rate peaked at 37.1 percent in 1992 and was still as high as 33 percent in 1999.

The quotas of effective unemployment would be even higher accounting for the number of early pensioners who were driven out of the labor force by tight labor market conditions and government incentives for early retirement. A vast majority of workers between age 55 and 65 (the normal retirement age) 
who lost their jobs did not return to employment, but entered pre-retirement schemes (DIW et al. (1999, p. 11). Until the end of 1992, labor market authorities financially supported early retirement of workers older than age 55. At the peak in 1993, some 893,000 former workers were paid one of the different types of early retirement settlements (Vorruhestandsgeld, Altersübergangsgeld). Although early retirement programs ran out in 1995, the working-age labor force was still relieved from close to 300,000 early pensioners during the year 1999.

A different way of illustrating the size of the unemployment problem in East Germany is to compare the present size of truly employed people to the size of employment at the end of 1989. At the beginning of the transformation, 9.89 million people were gainfully employed in the GDR. This number was reduced to 6.06 million in 1998. Subtracting the full-time equivalent of short-time work, the number of participants in employment creation programs and persons in further education results in 5.75 million persons who were effectively employed. This is only 58 percent of the size of employment at the time when the socialist system collapsed. Roughly speaking, every second worker has not regained her job in East Germany even after ten years of economic transformation.

As noted above, the formidable level of unemployment, which was a traumatic experience for many East Germans, enforced the introduction of labor market and social policy measures in order to avoid social tensions and out-migration. For the most part, the conventional labor market tools of the Federal Labor Office, the Bundesanstalt für Arbeit, were extended to the East. However, they were to some degree applied in a different manner.

As is evident from Figure 2, the focus of the labor market instruments employed changed over time. In the first period after unification when creation of fresh employment was expected to start before long, policy aimed at stretching out the unavoidable reduction of obsolete jobs. The Treuhandanstalt, the central privatization agency founded to privatize the state-owned enterprises, frequently negotiated job guarantees with private investors (at the expense of privatization profits), which ensured at least temporary job stability. The most important labor market instrument was the support of short-time workers under more favorable conditions than in the 
West. $^{2}$ Until the end of 1991, the Federal Employment Office heavily subsidized workers who frequently were producing nothing. At the peak in the first half of 1991, there were about 2 million short-term workers; the subsidized loss of working hours was equivalent to 1.1 million full-time jobs.

When most of the short-term workers became unemployed soon after, the emphasis of labor market policy shifted to employment creation programs, socalled Arbeitsbeschaffungsmaßnahmen (ABM), and government training schemes. Although the eastern labor force was seen to exhibit a comparatively high level of formal qualification attainment, ${ }^{3}$ western-style retraining was expected to improve the speed of labor market integration of East German workers. Chambers of commerce or private training companies were providing education and training under the monitoring of the Federal Labor Office.

Almost 500,000 unemployed persons participated in such training schemes during 1992. In the following years, training activities were gradually reduced, as the qualification demand was declining and the reputation of education programs to promote re-employment was coming into doubt. In 1999, only 138,000 persons took part in training activities. The share of the unemployed involved in training programs had almost converged to the western level.

In contrast, publicly financed work creation, intended to avoid qualification loss during periods of unemployment, has stayed a popular policy instrument to reduce registered unemployment in East Germany. In 1999, 18.9 percent of the unemployed benefited from the public creation of work, compared to only 2.7 percent in the West. The size of ABM participation $(351,000)$ was again almost as high as in the peak year 1992 $(388,000)$.

The rapid expansion of $\mathrm{ABM}$ in the eastern states was achieved through generous subsidies (covering all personnel and non-personnel costs) and a less rigid targeting of job creation measures, which are typically directed at

2 In Germany, labor market authorities usually support short-term work to bridge a temporary decline in demand or production.

3 The proportion of persons entering the labor market with an occupational credential was much higher in the East than in the West. Furthermore, a much higher proportion participated and completed apprenticeships and vocational training (Lange/Pugh (1998)). 
the hard-to-place unemployed in the West. During the first years of the transformation, the Federal Labor Office subsidized a large number of Beschäftigungsgesellschaften (employment companies) that were mostly set up from non-viable parts of Treuhand firms to provide training and jobs. At present, most workers involved in ABM are employed by specific firms to engage in public works that do not (or should not) compete with private enterprise. These firms pay tariff (or comparable) wages, subsidized between 80 and 100 percent by the Federal Labor Office (Brinkmann/Gottsleben (1994)). ${ }^{4}$

As an innovative instrument of publicly financed job creation in East Germany, specific wage subsidies (Lohnkostenzuschüsse Ost) were introduced in 1993. In contrast to the conventional job creation programs, coverage of the subsidies was limited to the amount of the average unemployment benefit. Since 1997, also private enterprise is eligible to this new type of wage subsidies, which might turn a useful instrument to promote reintegration into the first labor market.

At present, while the level of unemployment seems to be stabilizing on a stubbornly high level, the structure of employment in the East continues to differ significantly from that in the West. Table 1 shows how the structure of gainful employment across sectors has been developing after the unification. In 1991, there were some marked differences between the large aggregates agriculture (including forestry and fishing), the government sector, the producing sector, trade and transportation, and services. As the economically backward GDR had maintained the structure of an advanced industrial society, similar to that of West Germany in the mid-1960s (Grünert/Lutz (1995)), the employment share of the first three sectors was larger, that of the last two smaller than in the West. ${ }^{5}$

$4 \quad$ Wages of ABM participants initially even exceeded market wages in some regions. As a consequence, in 1993, the average hours of work in job creation programs was reduced, in order to avoid disincentives for market employment.

5 Analysis of employment shares gives a somewhat awkward impression of the actual economic weight of the manufacturing sector in eastern economy. In terms of gross product, the producing sector accounted for more than 50 percent in the GDR economy. 
Table 1 Sector Structure of Gainful Employment in East and West Germany (Percent of Total Gainful Employment)

\begin{tabular}{|c|c|c|c|c|c|c|c|}
\hline \multirow[b]{2}{*}{ Sector } & \multicolumn{7}{|c|}{ Year } \\
\hline & 1991 & 1992 & 1993 & 1994 & 1995 & 1996 & 1997 \\
\hline & \multicolumn{7}{|c|}{ East Germany } \\
\hline Agriculture & 6.2 & 4.4 & 3.7 & 3.6 & 3.5 & 3.4 & 3.5 \\
\hline Manufacturing & 40.8 & 35.7 & 34.9 & 34.9 & 34.9 & 34.2 & 33.7 \\
\hline Trade and & & & & & & & \\
\hline Transportation & 17.0 & 17.9 & 18.2 & 17.9 & 17.5 & 17.5 & 17.5 \\
\hline Services & 12.7 & 15.8 & 17.9 & 19.3 & 20.4 & 21.4 & 22.0 \\
\hline \multirow[t]{2}{*}{ Government } & 23.3 & 26.1 & 25.3 & 24.3 & 23.6 & 23.5 & 23.3 \\
\hline & \multicolumn{7}{|c|}{ West Germany } \\
\hline Agriculture & 3.3 & 3.2 & 3.0 & 2.9 & 2.8 & 2.7 & 2.6 \\
\hline Manufacturing & 39.2 & 38.4 & 37.1 & 36.1 & 35.6 & 34.7 & 34.0 \\
\hline $\begin{array}{l}\text { Trade and } \\
\text { Transportation }\end{array}$ & 19.0 & 19.2 & 19.3 & 19.3 & 19.1 & 19.1 & 19.1 \\
\hline Services & 19.2 & 19.9 & 20.8 & 21.6 & 22.4 & 23.2 & 23.9 \\
\hline Government & 19.3 & 19.4 & 19.7 & 20.0 & 20.1 & 20.3 & 20.5 \\
\hline
\end{tabular}

Source: German Statistical Yearbook, various issues.

Significant adjustments of the employment structure started to take place already in 1992. The employment share of agriculture and the producing sector declined rapidly (the latter below the West German level), whereas the service sector started to catch up to western standards. However, East German convergence on western sector patterns is far from complete after ten years of transition. In particular, the eastern government sector still appears as overstaffed, compared to western standards, as tasks are only hesitatingly being transferred to the private sector. The share of the public sector in gainful employment went up significantly with the employment crisis of 1991. This observation suggests that the government sector, not exposed to competition, was able to maintain a high number of low-productive workers, thereby implicitly subsidizing unemployment. 
Table 2 Occupational Position of Gainfully Employed in East and West Germany (Percent of Total Gainfully Employed)

\begin{tabular}{|c|c|c|c|c|c|c|c|c|}
\hline \multirow{2}{*}{$\begin{array}{l}\text { Employment } \\
\text { Position }\end{array}$} & \multicolumn{8}{|c|}{ Year } \\
\hline & 1991 & 1992 & 1993 & 1994 & 1995 & 1996 & 1997 & 1998 \\
\hline & \multicolumn{8}{|c|}{ East Germany } \\
\hline Self-Employed & 4.6 & 5.9 & 6.7 & 7.2 & 7.4 & 7.5 & 8.0 & 8.7 \\
\hline Civil Servant & 1.2 & 1.6 & 2.0 & 2.3 & 2.8 & 3.3 & 3.7 & 3.9 \\
\hline White Collar Worker & 48.9 & 49.8 & 49.1 & 49.0 & 47.5 & 46.2 & 46.5 & 47.4 \\
\hline Blue Collar Worker & 45.4 & 42.7 & 42.2 & 41.5 & 42.3 & 43.1 & 41.8 & 40.0 \\
\hline \multirow[t]{2}{*}{ Part-Time Workers $^{\mathrm{a}}$} & 1.9 & 1.7 & 2.0 & 2.4 & 2.9 & 3.7 & 4.3 & 4.8 \\
\hline & \multicolumn{8}{|c|}{ West Germany } \\
\hline Self-Employed & 10.8 & 10.7 & 10.8 & 11.2 & 11.2 & 11.2 & 11.5 & 11.7 \\
\hline Civil Servant & 8.2 & 7.9 & 7.9 & 7.9 & 7.7 & 7.7 & 7.6 & 7.3 \\
\hline White Collar Worker & 43.8 & 44.7 & 45.4 & 46.2 & 46.4 & 46.6 & 47.6 & 48.0 \\
\hline Blue Collar Worker & 37.2 & 36.7 & 35.9 & 34.7 & 34.6 & 34.5 & 33.3 & 33.0 \\
\hline Part-Time Workers $^{\mathrm{a}}$ & 8.9 & 9.4 & 9.7 & 10.1 & 10.7 & 11.4 & 12.2 & 12.7 \\
\hline
\end{tabular}

Note: (a) Weekly working time 20 hours or less.

Source: German Federal Statistical Office.

What seems more worrying with regard to the future employment outlook is the fact that the trade and transportation sector, where the employment share stagnated, and the service sector have not caught up fully to the West. Since 1995 the share of these sectors in overall gainful employment has been ranging about 3.5 percentage points below the western level. Thus, there appears to be little evidence that the East could leave the West behind as a modern service economy after completion of the transformation process. Of course, this interpretation refers only to the employment structure, not to the actual modernization of the enterprises behind this.

Table 2 surveys changes of the occupational position of the gainfully employed in East and West Germany. Again, the data show comparatively little evidence that employment patterns would converge between the two regions soon. The share of blue-collar workers among the gainfully employed, decreasing since unification, has stayed substantially higher in the East than 
in the West. In 1998 the fraction of blue-collar workers in East Germany was still 40 percent when the western rate had fallen to less than one third. At the same time, the portion of white-collar workers in the East had fallen below the West German level. The fraction of employees in the government sector, where the machinery of civil servants is building up only gradually, remained substantially smaller than in West Germany.

Two trends revealed in Table 2 might become relevant for the future employment prospects in the East. First, self-employment, starting from a very low level when the GDR economy collapsed, has made great progress after unification. In 1998, 8.7 percent of the gainfully employed in the East ran their own business. However, the level of entrepreneurial activity still lagged behind that in the West substantially. It might well be that the transformation process did not open up sufficient opportunities for private enterprise, in particular in small businesses that would promote dependent employment (Gruhler (1997)).

Secondly, the share of part-time employment, which has been increasing in the whole Germany over the last decade, remains significantly lower on the eastern labor market. Roughly speaking, for each three part-time workers employed in the West (working less than 20 hours a week), there was only one in the East in 1998. This finding hints at unexploited opportunities for labor reorganization in East Germany. Improving the flexibility of employment conditions may open up the chance to additional employment. Obviously, this reading of the current eastern job pattern does not say that there actually would be a demand for additional part-time employment. This has to be discussed further in Section 4. Before doing so, we survey the empirical evidence on the possibilities to improve eastern employment levels through measures of active labor market policy.

\section{The Effects of Active Labor Market Policy}

As discussed above, one reaction to the labor market problems in East Germany was massive expansion of active labor market policy. The main tools of active labor market policy in the East, educational training programs and $\mathrm{ABM}$, aimed at preserving and improving the qualification of the 
participants during periods of unemployment, in order to promote rapid reintegration into the first labor market. The effectiveness of active labor market measures in East Germany in reaching this goal has been studied extensively.

A simple analysis of participants' employment status shortly after completion of an $\mathrm{ABM}$ or qualification program seems to suggest that active labor market policies were rather successful. According to a specific survey of labor market data that has been conducted regularly in East Germany since the unification (Arbeitsmarktmonitor Ost), roughly one third of the participants in qualification programs and one quarter of the participants in job creation programs reentered the regular labor market shortly after termination of the program (DIW et. al. (1999), p. 56).

However, the relative success of active labor market policies is difficult to evaluate on the base of these data, since the labor market performance of the unemployed who did not take part in labor market programs is neglected. Econometric studies, which construct a control-group of non-participants to avoid this bias, have not come to an unanimous conclusion about the effectiveness of active of labor market policies in improving regular employment in the East.

In general, qualification programs seem to have promoted re-employment more successfully than job creation programs. Helberger/Pannenberg (1997), using data from the German Socio-Economic Panel (GSOEP), and Kraus et al. (1999), based on the Arbeitsmarktmonitor Ost, have been able to demonstrate positive employment effects (at least in the medium term) of the extensive retraining schemes that were offered by the Federal Labor Office in the first period after unification. Fitzenberger/Prey (1997) come to the same conclusion. However, they show that the positive employment effects were limited to vocational training schemes outside firms. With regard to publicly financed retraining on the job, the employment effect is revealed as insignificant, which suggests that the employment success of program participants was offset by displacement of other workers. Finally, Hübler (1996) has demonstrated that the employment effects of public retraining activities were possibly gender-specific. It appears that the positive employment impact was limited to men, while East German females did not significantly benefit from participation in educational programs. 
Challenging the results of previous studies, Staat (1997) and Lechner (1998) who reevaluate evidence from the GSOEP do not observe any significant improvement of chances to employment due to qualification measures. The latter furthermore observes that training and the chance to reenter the first labor market are inversely related in the short-term. One may conclude from this result that financial security during participation in educational programs reduced individual efforts to instantly regain regular employment.

According to the available evidence, public work creation through ABM was less successful in bringing workers back into stable employment on the first labor market than were retraining programs. Empirical evaluations of public works projects in East Germany by Steiner/Kraus (1995), Hübler (1997) and Kraus et al. (1998) uniformly indicate insignificant or even negative effects on the reemployment prospects of ABM participants in comparison to unemployed who did not join the program. There is only one notable exception: Using a regional labor market data set for the eastern state of Saxony-Anhalt, Eichler/Lechner (1998) have estimated a positive reemployment effect of public job creation.

One possible explanation for the unfavorable empirical assessment of the $\mathrm{ABM}$ measures is again that the participants search less intensively for regular employment. Furthermore, the institutional arrangements of public job creation programs, supporting labor-intensive work and old technologies (or inefficient utilization of new technologies), frequently do not meet with the current demand of the labor market, which promotes individual dequalification (Schultz (1997)). Thus participation in ABM appears to create a negative signal to potential employers, which reduces the chances for reemployment. The reason for the negative employment outcome is not a selective targeting of the ABM programs on disadvantaged groups on the labor market. As mentioned above, the terms of eligibility to ABM were less rigid in East Germany. In fact, Kraus et al. (1998) do not find evidence for adverse sample selection.

The weak impact of public job creation programs on individual employment performance casts serious doubt on their role as the central tool of active labor market policy in East Germany. Given that qualification measures are more likely to promote integration into the first labor market, 
policymakers may consider reallocating resources between the current measures of active labor market policy. This does not say that ABM would not be justified for social reasons. In fact, there is some evidence that provision of active labor market programs is used in East Germany as a social policy instrument cushioning the burdens of unemployment, in particular of long-term unemployment.

According to estimates based on the GSOEP, the net income of eastern households who benefit from active labor market measures amounts to some three quarters of the representative employment income. The income of such households is about as high (and even higher for participants in retraining programs) as that of households receiving passive unemployment support (Arbeitslosengeld) (DIW et al. (1999), p. 58). In West Germany, the relative income position of beneficiaries receiving active support is considerably less favorable: Participants in $\mathrm{ABM}$ or qualification programs receive only 60 percent and 64 percent, respectively, of the average employment income. Therefore, the household income of eastern participants in active labor market programs is almost equal (97 percent on a weighted average) to that of comparable western households.

Considered that the income support payments by the Federal Labor Office are normally linked to net wage income, which is still substantially lower in the East, this may be a surprising result. It is explained by strong regional disparities in labor market presence (discussed at length in Section 4). As a consequence, households with more than one transfer recipient are much more frequent in the East than in the West. For this reason, the fact that the income status of the eastern unemployed is more favorable relative to comparable westerners than the income status of persons who are in employment is also true for recipients of other transfers from the Federal Labor Office.

The distributional effects of active labor market tools are even more evident considering the development of unemployment income over time. In West Germany, the long-term unemployed typically gradually descend on the transfer income ladder, from unemployment support to unemployment assistance (Arbeitslosenhilfe) to social welfare. It appears that this process is slowed down in East Germany through the tools of active labor market policy. During the period from 1990 to 1997, the status of joblessness ended with participation in $\mathrm{ABM}$ or educational training programs for more than 
40 percent of the eastern unemployed. Furthermore, more than two thirds of the participants in active labor market policy were not reemployed after completion of the measure, or took part in a second program. By the end of 1997, one quarter of the long-term unemployed had participated in active labor market programs for more than 53 months.

This pattern suggests that active labor market policy has been exploited to perforate the period of unemployment (Schultz (1998)). The interruption of unemployment through program participation re-establishes claims on unemployment support payments. Thus, the perforation strategy manages to postpone gradual decline in unemployment transfer levels for the long-term unemployed.

\section{Sources of Unemployment}

Explaining what causes the high level of joblessness on the East German labor market, observers of the transformation process have referred to demand and supply side arguments. With regard to labor demand, a majority of analysts including Sinn/Sinn (1992), Siebert (1992), Link (1993), Sachverständigenrat (1997) and Lange/Pugh (1998) among others have stressed that the high (and rapidly growing) wages in the East are a major source of high unemployment rates and insufficient investment. Focusing on the supply side, some economists, notably Zimmermann (1993) and VoglerLudwig (1997), have argued that differences of labor market participation and hours of work are a major source for the higher level of eastern unemployment relative to the West. In the sequel, some stylized facts are gathered to check the validity of these arguments.

With the economic union, the West German system of trade unions and collective wage bargaining was immediately expanded to the East. Trade unions, lead by the widespread fear of massive east-west migration and the expectation of fast economic recovery, pressed for the rapid convergence of wages. ${ }^{6}$ Special collective agreements (Stufentarifverträge) were negotiated

6 The actual size of the migration pressure was certainly overestimated. Migration studies suggest that wage differentials are not so much relevant for migration decisions as unemployment differentials (Wagner (1992), Keil/Newell (1993), Bauer/Zimmermann (1998)). See Pischke et al. (1994) for an opposite position. 
that adjusted union wages stepwise to the western level over a short period of years. Full convergence of union wages was reached as early as 1995 in certain industries. In some major branches, including banking, construction, the metal and electronic industry, and the iron and steel producing industry full convergence was agreed upon the year 1997, although this still excluded certain extra payments and weekly working hours. In most other sectors, convergence of union wages, usually approaching between 80 and 90 percent of the western level, is also far advanced.

Considering the generally low level of labor productivity after the breakdown of the socialist economy, wage setting in East Germany certainly did not follow the logic of neoclassical equilibrium theory in the first period after unification (Schmidt/Sander (1993)). Nevertheless, the relevance of wage policy for the recovery of employment (or rather the lack of it) seems to have been largely overestimated. ${ }^{7}$ Figure 3 allows comparing the development of monthly tariff wages, gross effective wages and labor productivity (measured in terms of gross output per worker) relative to the respective western level. ${ }^{8}$

As the wage drift has been substantial, the focus on union wages seriously exaggerates the actual differential between wage costs and labor productivity. Effective wages have been converging to western standards more slowly than union wages for several reasons. First, payment above tariff, frequent in the West, is very rare practice in the eastern states (DIW et al. (1994)). Secondly, eastern workers often do not receive extra payments (Urlaubsgeld, Weihnachtsgeld) that are quite standard in West Germany. Finally, tariff wages did not prevail on the labor market frequently. A growing number of East German companies seem to exploit opportunities to pay wages below tariff. In 1998, 79 percent of the companies in the producing sector did not participate in collective wage bargaining, many of them paying wages below

$7 \quad$ Thimann (1996) and Fitzroy/Funke (1998) study the conflict between wage setting and employment in East Germany quantitatively.

$8 \quad$ Given the complex and confusing system of collective wage agreements, it is very difficult to aggregate union wages on a sector level. Productivity and effective wage measures are not readily available on the industry level. The presentation of Figure 3 claims that productivity growth in the producing sector as a whole would resemble that in the metal and electrical sector. Of course, comparisons on the aggregate level between the East and West are problematic, due to the different industry and employment structures of the two regions. 
tariff (DIW et al. (1999), p. 62). In addition, in a significant number of firms that take part in the collective bargaining process formally, internal agreements have been reached with Works Councils and workers to pay less than tariff wages in order to preserve employment.

Figure 3 Union Wages, Effective Wages and Labor Productivity in East Germany (Index West Germany = 100)

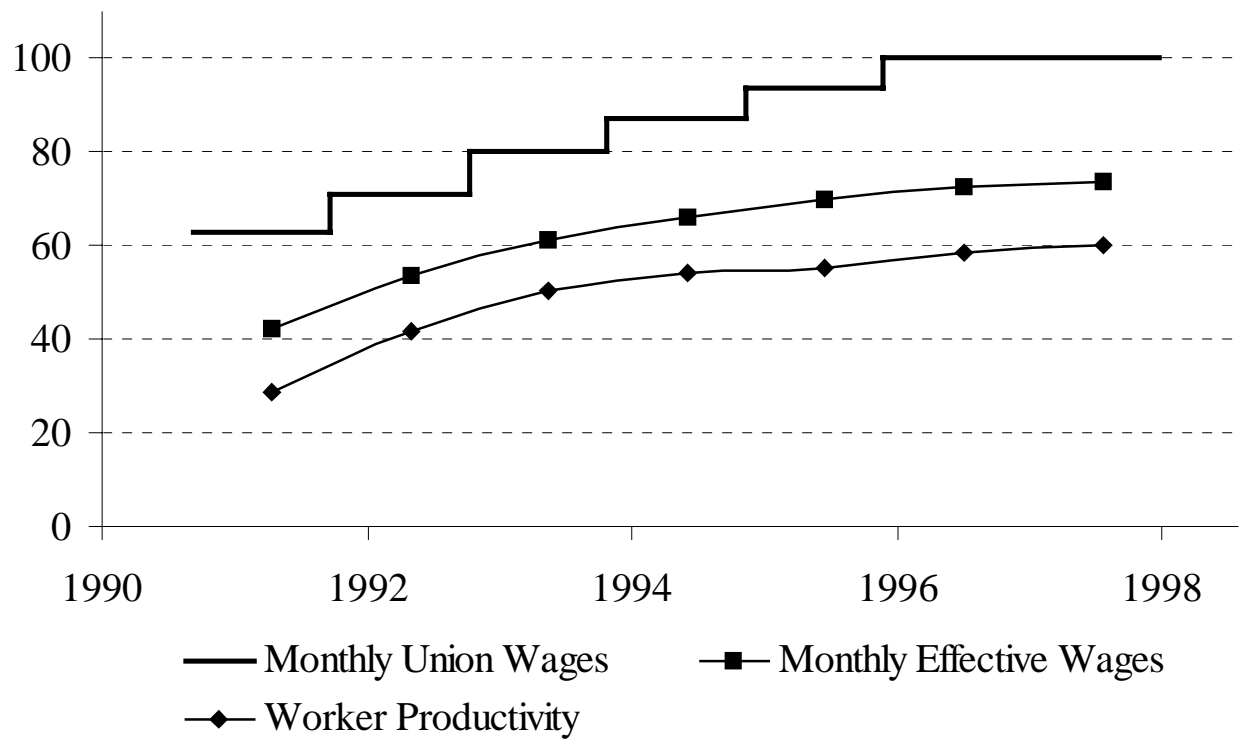

Notes: Productivity measured by gross product per worker in the production sector. Monthly effective wages in the production sector. Monthly union wages in the metal and electrical industry.

Sources: Sachverständigenrat, Yearly Report, various issues; German Statistical Yearbook, various issues, Boje/Schneider (1995).

The rapid adaptation of the wage setting process to the transformation crisis has been preventing wage convergence as aimed at by the (western dominated) trade unions. As displayed in Figure 3, effective wages in the East had reached only about three quarters of the western level in 1997 when eastern output per worker was close to 60 percent of that in the West. Moreover, since the wedge between effective wages and labor productivity of some 15 percentage points stayed largely unchanged in the course of the 
transformation process, the productivity gap since unification has been declining substantially in relative terms.

The argument that inadequate wage policy is fundamental to the high level of eastern unemployment might be challenged also for theoretical reasons. Certainly, wages should follow productivity in an equilibrium state. However, it is less certain that the equilibrium concept would provide a valuable answer to the problems of the East German economy during transformation. As the capital stock of the GDR was obsolete, most East German goods would not have sold at any level of socially acceptable real wages. Higher wages, however, should be no problem for a capital stock that is newly built up. Modern technology can pay high wages. In this perspective, the initial rapid wage increase in the East set incentives for creative destruction. A low wage policy in East Germany would have resulted in a low productivity capital stock, associated with very slow convergence to the West. Given that this strategy was no realistic policy option, the question then is why investors hesitated to reconstruct and modernize the eastern capital stock to pay high productivity wages. (Section 5 will provide some possible answers.)

As shortage of employment is a relative phenomenon, the high rates of joblessness reported for East Germany might be due to supply factors. One of the marked differences on the labor market between the former GDR and the FRG was exhibited by the labor force participation rates, which were substantially higher in the East where politics had set strong incentives to encourage employment. Overall labor force participation in East Germany was 78.1 percent in the age group from 15 to 65 in 1988 when the same number was 68.8 percent in the former FRG. Figure 4, which depicts the development of eastern labor force participation rates relative to the western standard, shows that the strong regional differences in labor supply behavior have persisted during the transformation process. The presence of East Germans at employable age on the labor market, although declining after the unification, still was some 8 percent higher than that of representative westerners in 1998. Furthermore, there appears to be little evidence at present that East Germans would adapt to the labor supply behavior of their western countrymen soon. 
Figure 4 also highlights some considerable gender disparities. While labor force participation of eastern males consistently has been similar to that of western males, the propensity of females to seek employment is still substantially higher in the East than in the West. The communist eastern leaders had tried to overcome traditional gender roles promoting women to work. As a consequence, female labor force participation in the former GDR ranked among the highest in the world. In 1988, 75.7 percent of women at employable age participated in the eastern labor force (most of them employed as there was practically full employment), compared to 55.0 percent in West Germany where the age-pattern of female participation conventionally follows the family life-cycle.

In contrast to what many observers of the transformation process had expected, the propensity of East German women to take up a job did not converge to western standards after unification, despite rising obstacles to get employed. ${ }^{9}$ Considering the comparatively low eastern wage levels, one explanation for this behavior appears to be the necessity to maintain family income. This may explain why labor force participation of East German married females, which is still ranging more than 35 percent above that of comparable western females, has remained particularly high.

While labor supply was staying at uncommonly high levels, employment opportunities for female workers narrowed substantially. In the consequence, the eastern female unemployment rate was almost double that of males in certain years. Women also had serious trouble to get reemployed. According to estimates by Gladisch/Trabert (1995), as many as 89.6 percent of new regular employment opportunities were taken up by men during the period from 1992 to 1994. The low marginal employment share of females does not necessarily imply discrimination. Other factors, including differences in regional mobility and qualification structure (including retraining possibilities) might have played a role (Lange/Pugh (1998), p. 104).

With strong regional disparities in labor supply persisting, a reduction of eastern unemployment to the western standard certainly cannot be expected. Furthermore, the focus on unemployment rates appears to misrepresent the

9 In the former GDR, female employment was supported, for example, by generous provision of day care for children. This institution was rapidly dismantled after the unification. 
severity of the employment crisis in East Germany. To assess the actual size of the employment problem, it is only of interest to what extent potential labor is needed. As mentioned above, 6.06 million persons were gainfully employed in the East in 1998. Given the population size at employable age of 10,7 million, the effective eastern employment rate was 56.4 percent, some 5 percentage points lower than the corresponding employment rate for West Germany (61.7 percent). Although the effective employment levels in the East, which had exceeded those in the West until 1991, have stabilized below the western standard in recent years, shortage of employment opportunities in the

East is

Figure 4 Labor Force Participation Rates in East Germany (Index West Germany $=100$ )

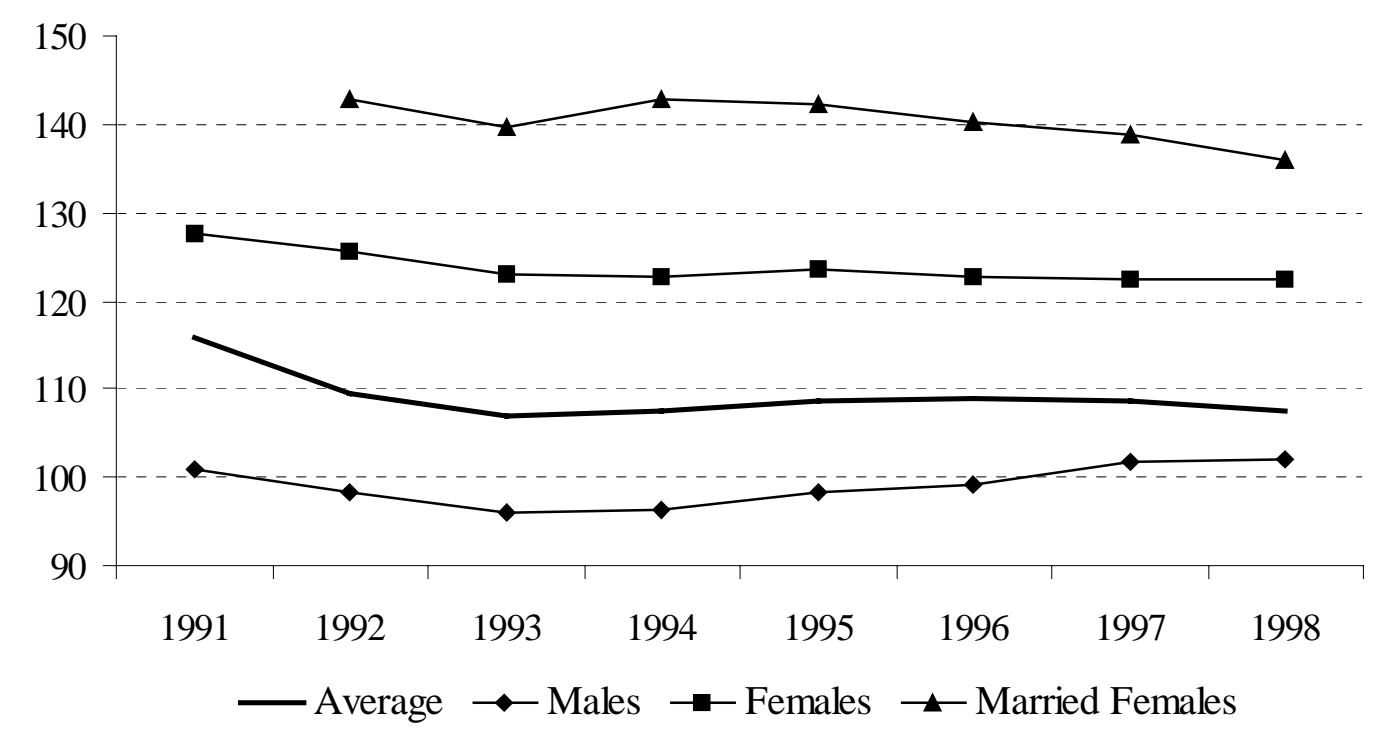

Sources: Sachverständigenrat, Yearly Report, various issues; German Statistical Yearbook, various issues.

beyond doubt less substantial than the focus on regional differences in unemployment does suggest.

This is even more evident considering the effective volume of eastern employment, rather than the share of effectively employed workers. Collectively agreed-upon working hours in East Germany have not converged to the western level. On average, union working time is still exceeding that in 
the West by about two hours per week. When measured in terms of the yearly hours worked per gainfully employed, the eastern advantage in effective employment volume is even more substantial. As is indicated in Figure 5, labor volume per individual worker in the East consistently surpassed that in the West. ${ }^{10}$ Furthermore the individual employment volume is only slowly converging to western standards. In 1998, eastern workers were still occupied about 6 percent longer than western workers. The regional differences of

Figure 5 Yearly Employment Volume in East Germany $($ Index West Germany $=100)$

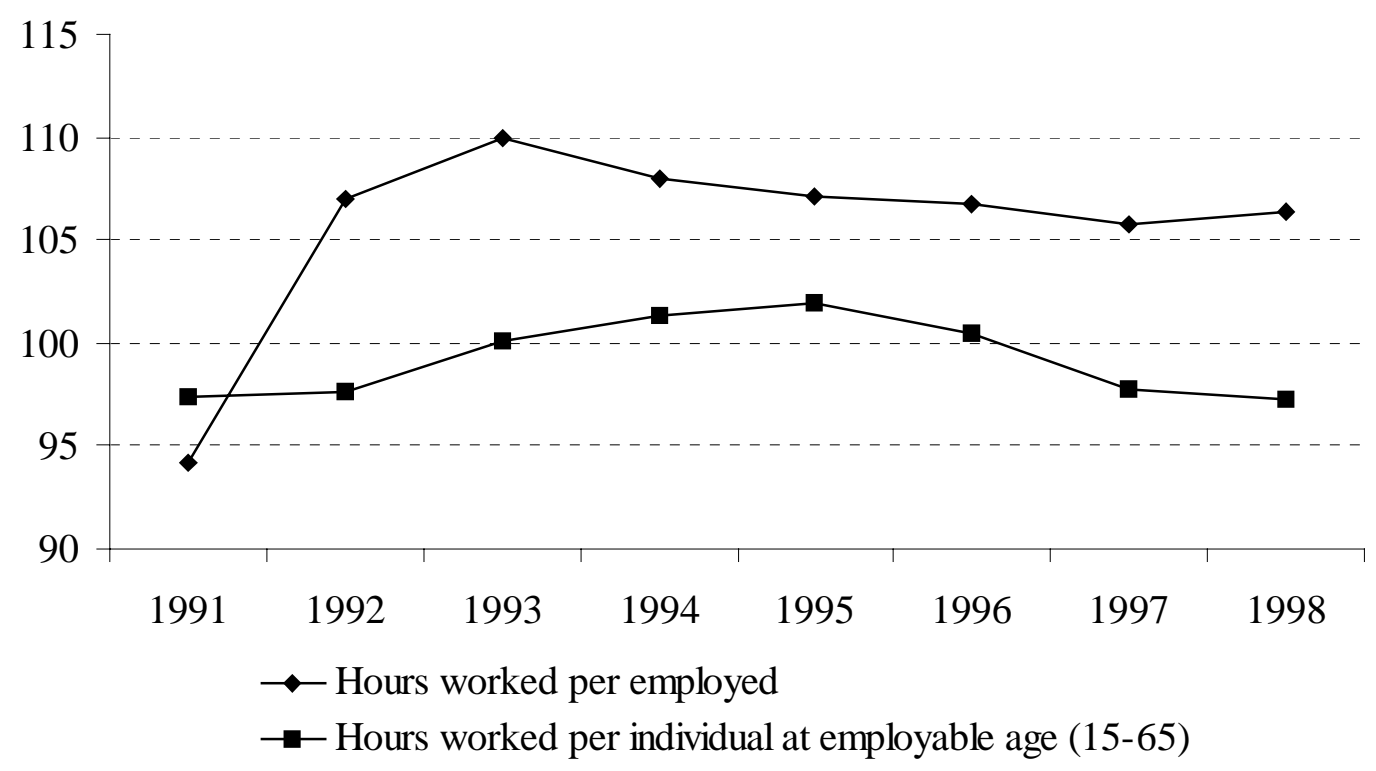

Sources: Ministery of Labor and Social Affairs, Statistisches Taschenbuch Arbeits- und Sozialstatistik 1999; own calculations.

individual employment volume are only partially due to the less generous tariff agreements. They also reflect the considerable shortage of part-time occupations on the East German labor market.

The remarkable advantage of East Germany in terms of individual employment volume suggests that there would be some opportunities for reallocating employment. In fact, had working hours in the East been

10 The only exception is observed in 1991 when many workers were put on short-term employment. Annual employment volume per worker recovered, as soon as obsolete workers were driven out of their jobs after 1992. 
distributed according to the western standard, the size of gainful employment in 1998 could have been some 390,000 persons higher. The corresponding effective employment quota of 60 percent would have come very close to the observed western employment rate of 61.7 percent. A similar result is displayed in Figure 5. Constructing the volume of hours worked relative to the size of the population at employable age, there appears to be no substantial shortage of employment opportunities in the East, relative to the western standards. From this perspective, effective eastern employment volume, which even exceeded the western level during parts of the transformation process, was less than three percentage points below the western rate in 1998.

To avoid misunderstandings, it should be stressed that this type of calculation does not imply that the large size of unemployment in East Germany is not a real social problem. Nevertheless, it has to be emphasized that a remarkable adjustment of the overall employment volume has already taken place. Given that wages and labor productivity are converging to western standards, it is unlikely that the overall employment volume in the East would stabilize above the western level and absorb the more ample eastern labor supply.

\section{Missed Opportunities?}

The Federal Government policies in the process of unification had the objectives of a fast establishment of the market system, modernization of the eastern capital stock and a smooth adjustment of the labor market. These goals were to be achieved through the monetary, economic and social union which less than eight months after the fall of the Berlin wall expanded the pre-existing West German institutions, standards and practices to the East. Looking back ten years after the unification, there is hardly any doubt that there was no gradualist alternative to the big bang approach of fast economic integration taken. Nevertheless, considering the stagnant economic recovery of the eastern states and persisting regional disparities, especially from a labor market perspective, one may ask what opportunities were missed in the course of the economic transformation. 
In historical perspective, a major political mistake during the early stages of the unification process was to underestimate and even deny the economic and social costs associated with the eastern transition to a modern market economy. For example, considering the over-employment promoted by the communist system, it was an illusion to believe that gainful employment in the East could have been maintained at the pre-unification level. (It seems that this point is still not well understood by some political decision makers.) As a consequence, individuals' willingness to share in the burdens of unification was substantially weakened in East and West Germany alike.

Due to the political myth of smooth and fast economic integration, the challenge of transforming the eastern socialist command economy was not widely perceived as an opportunity for re-thinking the political and economic system in Germany as a whole. The total collapse of the socialist system rather reinforced confidence that the East German society would adapt to the western institutions without frictions. Thus, a frequent attitude in the West was that the reunited Germany should simply become an enlarged Federal Republic. However, many of the institutions that were expanded without change to the eastern states were impeding economic progress in the West already before unification. It is therefore hardly surprising that the systemic problems aggravated when the eastern transition crisis called for greater flexibility. From the vantage point ten years after unification, it appears that lack of institutional innovation during the transformation process imposed (and is still imposing) the most serious obstacles to recovery of the East German economy which continues to be equipped with too little capital to create sufficient new employment opportunities.

The general reluctance of institutional renewal obstructed, for example, the establishment of efficient government structures. After the dismantling of the communist administrative body, public administration in the eastern states was first largely rebuilt after western examples. Hence the opportunity was missed to immediately install modern techniques of governmental management that could have provided the flexibility required coping with the complex administrative problems occurring in the transformation process. Even at present, (local) administration in the East follows less up-to-date standards on average than in the West (Maaß (1999)). 
Ineffective government institutions certainly discouraged private investment. In particular, reconstruction of the mostly outdated eastern infrastructure, prerequisite to foster private capital formation, was slowed down considerably. Public investment, in comparison to transfers for consumption purposes, was dangerously low at the beginning of the transformation process. The gap in public infrastructure, thus, has been closed only partially. At present, the value of public assets in the East still lags behind the western level by about one quarter (DIW (2000)).

Furthermore slow decision processes, for example concerning the issue of restitution (which had been given preference over compensation of expropriated former owners) caused insecurities that held back investment. The difficult conditions of local administration may provide an explanation why the generous investment incentives introduced by the Federal Government to promote capital formation were only a partial success.

Pressure for convergence of institutions has also prevented East Germany to go ahead with the overdue revitalization of the German education system. Instead, the eastern states swiftly adapted to the unreformed West German educational standards of vocational and university training. (To give credit where it is due, there were certain advancements regarding secondary schooling.) Doing so, East Germany missed the opportunity to obtain a competitive advantage over the West, as shortage of well-trained and welleducated young workers is rapidly getting a bottleneck for economic growth in Germany as a whole. In addition, it seems likely that the network advantages coupled with the foundation of highly competitive research institutions would have enhanced eastern growth prospects, at least in the medium term, by promoting still insufficient private research activities.

A final example of perhaps inadequate convergence is given by the initially unqualified adaptation to pre-existing labor market institutions in East Germany. The practice of universal collective bargaining taken over from the West exerted decisive influence on the rapid increase of eastern labor costs and hence the loss of competitiveness during the first period after unification. In addition, acceptance of the highly regulated working conditions in the West was incompatible with the need for more flexible labor organization acute on the eastern labor market in transition. The mass 
unemployment in East Germany detected the inflexibilities of the traditional German labor market institutions all too cruelly.

Fortunately, there are some signs that the deep transformation crisis in the eastern states, which discredited many western routines, also fosters institutional renewal. The progressive loss of membership in unions and employers' associations and the establishment of bargaining practices at plant level ignoring industry guidelines demonstrate that the eastern society is capable to independent initiative.

Encouraging such initiative further appears important to solve the problems of transformation, which cannot be achieved through duplication but only through modernization of western structures. If eastern developments catalyzed institutional innovation in West Germany, the challenge of unification could open the opportunity for creative systemic competition, improving the prospects for recovered economic dynamism in Germany as a whole. 


\section{References}

Akerlof, G. et al. (1991), East Germany in from the Cold: The Economic Aftermath of Currency Union, Brookings Papers on Economic Activity $1,1-87$.

Bauer, T./Zimmermann, K. F. (1998), Causes of International Migration: An Overview, in: Gorter, C./Nijkamp, P./Poot, J (eds.), Crossing the Borders, Regional and Urban Perspectives on International Migration, Aldershot, 95-127.

Boje, J./Schneider, H. (1995), Der Umbruch am ostdeutschen Arbeitsmarkt, in: R. Pohl (ed.), Herausforderung Ostdeutschland, Fünf Jahre Währungs-, Wirtschafts- und Sozialunion, Berlin, 121-138.

Brenke, K./Schmidt, K.-D. (1999), Sektorale Produktions- und Beschäftigungsstrukturen in den neuen Bundesländern, in: E. Wiedemann (ed.), Die arbeitsmarkt- und beschäftigungspolitische Herausforderung in Ostdeutschland, Nuremberg, 95-113.

Brinkmann. C./Gottsleben, V. (1994), Labour Market and Labour Market Policy in the Eastern Part of Germany: New Approaches and New Links to Structural Policy, Labour 8, 505-520.

DIW (2000), Infrastrukturausstattung und Nachholbedarf in Ostdeutschland, Berlin.

DIW et al. (1994), Gesamtwirtschaftliche und unternehmerische Anpassungsfortschritte in Ostdeutschland, Zehnter Bericht, Kiel Discussion Paper 231, Kiel Institute of World Economics, Kiel.

DIW et al. (1999), Gesamtwirtschaftliche und unternehmerische Anpassungsfortschritte in Ostdeutschland, Neunzehnter Bericht, Kiel Discussion Paper 346/347, Kiel Institute of World Economics, Kiel.

Fitzenberger, B./Prey, H. (1997), Assessing the Impact of Training on Employment: The Case of East Germany, ifo-Studien 43, 71-116.

Gladisch, D./Trabert, L. (1995), Geschlechtsspezifische Differenzierung der Erwerbsbeteiligung, Wirtschaft im Wandel 1, 8-11.

Gruhler, W. (1997), Beschäftigung in mittelständischen Betrieben Ost- und Westdeutschlands, iw-trends 24, 55-66. 
Grünert, H./Lutz, B. (1995), East German Labor Market in Transition: Segmentation and Increasing Disparity, Industrial Relations Journal 26, 221-240.

Helberger, C. and Pannenberg, M. (1997), Kurzfristige Auswirkungen staatlicher Qualifizierungsmaßnahmen in Ostdeutschland: das Beispiel Fortbildung und Umschulung, in: Timmermann, D. (ed.), Bildung und Arbeit in Ostdeutschland, Berlin, 77-97.

Hübler, O. (1997), Evaluation beschäftigungspolitischer Maßnahmen in Ostdeutschland, Jahrbücher für Nationalökonomie und Statistik 216, 2144.

Keil, M./Newell, A. (1993), Internal Migration and Unemployment in Germany: An Anglo-Irish Perspective, Weltwirtschaftliches Archiv 129, 514-536.

Kraus, F. et al. (1998), Do Public Works Programs Work? Some Unpleasant Results from the East German Experience, Discussion Paper 98-07, Center for European Policy Research, Mannheim.

Kraus, F. et al. (1999), Employment Effects of Publicly Financed Training Programs - The East German Experience, Jahrbücher für Nationalökonomie und Statistik 219, 216-248.

Lange, T./Pugh, G. (1998), The Economics of German Unification, Cheltenham.

Lechner, M. (1998), Training the East German Labour Force, Heidelberg.

Link, F. (1993), Lohnpolitik in Ostdeutschland aus ökonomischer und sozialer Perspektive, Cologne.

Maaß, C. (1999), Der lange Weg der Reform - Eine Zwischenbilanz zu den Modellkommunen in Brandenburg, Landes- und Kommunalverwaltung Supplement I/99, 23-27.

Pischke, J.-S. et al. (1994), Arbeitslosigkeit, Löhne oder Weiterbildung: Warum pendeln Ostdeutsche in den Westen?, in: König, H./Steiner, V. (eds.), Arbeitsmarktdynamik und Unternehmensentwicklung in Ostdeutschland, Baden-Baden, 311-343.

Sachverständigenrat zur Begutachtung der gesamtwirtschaftlichen Entwicklung (1997), Jahresgutachten 1997/98: Wachstum, Beschäftigung und Währungsunion - Orientierungen für die Zukunft, Stuttgart. 
Schmidt, K.-D./Sander, B. (1993), Wages, Productivity and Employment in Eastern Germany, in: Ghaussy, A./Schäfer, W. (eds.), The Economics of German Unification, London, 60-72.

Schultz, B. (1997), Förderanreize im Widerspruch zu qualifikatorischen Zielen von Beschäftigungsmaßnahmen?, Wirtschaft im Wandel 3, 8-12.

Schultz, B. (1998), Hohe Verfestigung der Arbeitslosigkeit in Ostdeutschland, Wirtschaft im Wandel 4, 3-8.

Siebert, H. (1992), Das Wagnis der Einheit, Stuttgart.

Sinn, G./Sinn, H.-W. (1992), Jumpstart - The Economic Unification of Germany, Cambridge.

Staat, M. (1997), Empirische Evaluation von Fortbildung und Umschulung, Baden-Baden.

Steiner, V./Kraus, F. (1995), Haben Teilnehmer an Arbeitsbeschaffungsmaßnahmen in Ostdeutschland bessere Wiederbeschäftigungschancen als Arbeitslose?, in: Steiner, V./Bellmann, L. (eds.), Mikroökonomik des Arbeitsmarktes, Nuremberg, 387-423.

Thimann, C. (1996), Aufbau von Kapitalstock und Vermögen in Ostdeutschland: Der lange Weg zur Einheitlichkeit der Lebensverhältnisse, Tübingen.

Vogler-Ludwig, K. (1997), Arbeitsmarkt Ost: Ist die Beschäftigungspolitik am Ende?, in: Oppenländer, K. (ed.), Wiedervereinigung nach sechs Jahren: Erfolge, Defizite und Zukunftsperspektiven im Transformationsprozeß, Berlin, 233-248.

Wagner, G. (1992), Arbeitslosigkeit, Abwanderung und Pendeln von Arbeitskräften der neuen Bundesländer, Sozialer Fortschritt 41, 84-89.

Zimmermann, K. F. (1993), Labour Responses to Taxes and Benefits in Germany, in: Atkinson, A. B./Morgenson, G. V. (eds.), Welfare and Work Incentives: A North European Perspective, Oxford, 192-240. 


\section{IZA Discussion Papers}

\begin{tabular}{|c|c|c|c|c|}
\hline No. & Author(s) & Title & Area & Date \\
\hline 91 & M. Lechner & $\begin{array}{l}\text { Identification and Estimation of Causal Effects of } \\
\text { Multiple Treatments Under the Conditional } \\
\text { Independence Assumption }\end{array}$ & 6 & $12 / 99$ \\
\hline 92 & R. E. Wright & The Rate of Return to Private Schooling & 5 & $12 / 99$ \\
\hline 93 & M. Lechner & $\begin{array}{l}\text { An Evaluation of Public-Sector-Sponsored } \\
\text { Continuous Vocational Training Programs in East } \\
\text { Germany }\end{array}$ & 6 & $12 / 99$ \\
\hline 94 & $\begin{array}{l}\text { M. Eichler } \\
\text { M. Lechner }\end{array}$ & $\begin{array}{l}\text { An Evaluation of Public Employment Programmes } \\
\text { in the East German State of Sachsen-Anhalt }\end{array}$ & 6 & $12 / 99$ \\
\hline 95 & $\begin{array}{l}\text { P. Cahuc } \\
\text { A. Zylberberg }\end{array}$ & Job Protection, Minimum Wage and Unemployment & 3 & $12 / 99$ \\
\hline 96 & $\begin{array}{l}\text { P. Cahuc } \\
\text { A. Zylberberg }\end{array}$ & $\begin{array}{l}\text { Redundancy Payments, Incomplete Labor } \\
\text { Contracts, Unemployment and Welfare }\end{array}$ & 3 & $12 / 99$ \\
\hline 97 & A. Barrett & $\begin{array}{l}\text { Irish Migration: Characteristics, Causes and } \\
\text { Consequences }\end{array}$ & 1 & $12 / 99$ \\
\hline 98 & $\begin{array}{l}\text { J.P. Haisken-DeNew } \\
\text { C. M. Schmidt }\end{array}$ & $\begin{array}{l}\text { Industry Wage Differentials Revisited: A } \\
\text { Longitudinal Comparison of Germany and USA }\end{array}$ & $1 / 5$ & $12 / 99$ \\
\hline 99 & R. T. Riphahn & $\begin{array}{l}\text { Residential Location and Youth Unemployment: } \\
\text { The Economic Geography of School-to-Work- } \\
\text { Transitions }\end{array}$ & 1 & $12 / 99$ \\
\hline 100 & $\begin{array}{l}\text { J. Hansen } \\
\text { M. Lofstrom }\end{array}$ & $\begin{array}{l}\text { Immigrant Assimilation and Welfare Participation: } \\
\text { Do Immigrants Assimilate Into or Out-of Welfare? }\end{array}$ & $1 / 3$ & $12 / 99$ \\
\hline 101 & $\begin{array}{l}\text { L. Husted } \\
\text { H. S. Nielsen } \\
\text { M. Rosholm } \\
\text { N. Smith }\end{array}$ & $\begin{array}{l}\text { Employment and Wage Assimilation of Male First } \\
\text { Generation Immigrants in Denmark }\end{array}$ & 3 & $1 / 00$ \\
\hline 102 & $\begin{array}{l}\text { B. van der Klaauw } \\
\text { J. C. van Ours }\end{array}$ & $\begin{array}{l}\text { Labor Supply and Matching Rates for Welfare } \\
\text { Recipients: An Analysis Using Neighborhood } \\
\text { Characteristics }\end{array}$ & $2 / 3$ & $1 / 00$ \\
\hline 103 & K. Brännäs & $\begin{array}{l}\text { Estimation in a Duration Model for Evaluating } \\
\text { Educational Programs }\end{array}$ & 6 & $1 / 00$ \\
\hline 104 & S. Kohns & $\begin{array}{l}\text { Different Skill Levels and Firing Costs in a } \\
\text { Matching Model with Uncertainty - } \\
\text { An Extension of Mortensen and Pissarides (1994) }\end{array}$ & 1 & $1 / 00$ \\
\hline 105 & $\begin{array}{l}\text { G. Brunello } \\
\text { C. Graziano } \\
\text { B. Parigi }\end{array}$ & $\begin{array}{l}\text { Ownership or Performance: What Determines } \\
\text { Board of Directors' Turnover in Italy? }\end{array}$ & 1 & $1 / 00$ \\
\hline
\end{tabular}


1979 - 1990: An analysis of the (West-)German multivariate failure times and unobserved heterogeneity

107 J. C. van Ours G. Ridder

J. Boone

J. C. van Ours

109 G. J. van den Berg

B. van der Klaauw

110 D. DeVoretz

C. Werner

111 V. Sorm

K. Terrell

112

L. Bellmann

T. Schank

113 R. Euwals

114 G. Brunello

A. Medio

115 A. Cigno

F. C. Rosati

116

C. Belzil

S. Bender

A. Haas

C. Klose

118 M. A. Shields

M. E. Ward

119 A. Lindbeck

D. J. Snower

120 P. T. Pereira

P. S. Martins

121

J. C. van Ours

122

D. Munich

J. Svejnar

K. Terrell

123 J. Hunt
Fast Track or Failure: A Study of the Completion

Rates of Graduate Students in Economics

Modeling Financial Incentives to Get Unemployed Back to Work

Combining Micro and Macro Unemployment

Duration Data

A Theory of Social Forces and Immigrant Second

Language Acquisition

Sectoral Restructuring and Labor Mobility:

A Comparative Look at the Czech Republic

Innovations, Wages and Demand for

5

$1 / 00$

Heterogeneous Labour: New Evidence from a

Matched Employer-Employee Data-Set

Do Mandatory Pensions Decrease Household

Savings? Evidence for the Netherlands

An Explanation of International Differences in

Education and Workplace Training

Why do Indian Children Work, and is it Bad for

3

$2 / 00$

Them?

Unemployment Insurance and Subsequent Job

Duration: Job Matching vs. Unobserved

Heterogeneity

IAB Employment Subsample 1975-1995.

Opportunities for Analysis Provided by the

Anonymised Subsample

Improving Nurse Retention in the British National

Health Service: The Impact of Job Satisfaction on

5

$2 / 00$

Intentions to Quit

The Division of Labor and the Market for

Organizations

Does Education Reduce Wage Inequality?

Quantile Regressions Evidence from Fifteen

European Countries

3

$2 / 00$

$2 / 00$

Do Active Labor Market Policies Help Unemployed $\quad 4 / 6 \quad 3 / 00$

Workers to Find and Keep Regular Jobs?

Returns to Human Capital under the Communist

Wage Grid and During the Transition to a Market

4

$3 / 00$

Economy

Why Do People Still Live in East Germany? 
125 F. Büchel of Social Assistance Benefits

J. R. Frick

The Income Portfolio of Immigrants in Germany $1 / 3$

$3 / 00$

Effects of Ethnic Origin and Assimilation. Or:

Who Gains from Income Re-Distribution?

126 J. Fersterer

Smoking, Discount Rates, and Returns to

R. Winter-Ebmer

Education

127 M. Karanassou

Characteristics of Unemployment Dynamics: The

Chain Reaction Approach

D. J. Snower

Do Unemployment Insurance Recipients Actively

Seek Work? Evidence From Randomized Trials in

Four U.S. States

129 B. R. Chiswick

M. E. Hurst

The Employment, Unemployment and

Unemployment Compensation Benefits of

Immigrants

130 G. Brunello

S. Comi

C. Lucifora

The Returns to Education in Italy: A New Look at

5

$3 / 00$

the Evidence

131 B. R. Chiswick

132

R. A. Hart

Are Immigrants Fa

Hours and Wages in the Depression: British 7

133 D. N. F. Bell

Paid and Unpaid Overtime Working in Germany and 1

R. A. Hart

O. Hübler

W. Schwerdt

the UK

134 A. D. Kugler

G. Saint-Paul

135 A. Barrett

P. J. O'Connell

136 M. Bräuninger

M. Pannenberg

Hiring and Firing Costs, Adverse Selection and

3

$3 / 00$

Long-term Unemployment

Is There a Wage Premium for Returning Irish

$3 / 00$

Migrants?

Unemployment and Productivity Growth: An

$3 / 00$

Empirical Analysis within the Augmented Solow

3

Model

137 J.-St. Pischke

Continuous Training in Germany

138 J. Zweimüller

R. Winter-Ebmer

Firm-specific Training: Consequences for Job

Mobility

139 R. A. Hart

Y. Ma

Wages, Hours and Human Capital over the

$3 / 00$

140 G. Brunello

Life Cycle

1

Education and Earnings Growth: Evidence from $11 \quad$ 2/5 4/00

S. Comi

European Countries

141 R. Hujer

M. Wellner

The Effects of Public Sector Sponsored Training on

Individual Employment Performance in East

6

$4 / 00$

Germany 

both Worlds?

Does the Recent Success of Some OECD Countries in Lowering their Unemployment Rates Lie in the Clever Design of their Labour Market Reforms?

Employment Effects of Labour Taxation in an Efficiency Wage Model with Alternative Budget Constraints and Time Horizons

149 R. Lalive

J. C. van Ours

J. Zweimüller

150 J. DiNardo

K. F. Hallock

J.-St. Pischke

$151 \quad$ M. Ward

152 J. J. Dolado

F. Felgueroso

J. F. Jimeno

153 A. S. Kalwij

M. Gregory

154 M. Gerfin

M. Lechner

155 J. Hansen

156 C. Dustmann

F. Fabbri

157 P. Apps

R. Rees

158 A. Björklund

T. Eriksson

M. Jäntti

O. Raaum

E. Österbacka

The Impact of Active Labor Market Programs and Benefit Entitlement Rules on the Duration of

Unions and the Labor Market for Managers

Gender, Salary and Promotion in the Academic Profession

The Role of the Minimum Wage in the Welfare 3

Microeconometric Evaluation of the Active Labour 6

The Duration of Immigrant
Evidence from Sweden

Language Proficiency and Labour Market Per- 1

formance of Immigrants in the UK

Household Production, Full Consumption and $\quad 7$ the Costs of Children

Brother Correlations in Earnings in Denmark, 5 Finland, Norway and Sweden Compared to the United States 
A Comparison of the Human Capital and Signaling Models: The Case of the Self-Employed and the Barrachina

Selection Correction in Panel Data Models: An Application to Labour Supply and Wages The Recent Danish Experience

Wages and the Demand for Health - A Life Cycle Analysis

Reforming the Financial Incentives of the Welfare System Skilled Immigrants in the United States 
177 B. R. Chiswick

G. Repetto

178 R. Euwals M. Ward

179 E. Wasmer

P. Weil

180 T. K. Bauer

I. N. Gang

181 E. Wasmer

Y. Zenou

182 M. Fertig

C. M. Schmidt

183 M. Fertig

C. M. Schmidt

184 M. Corak

B. Gustafsson

T. Österberg

185 H. Bonin

K. F. Zimmermann
Immigrant Adjustment in Israel: Literacy and

Fluency in Hebrew and Earnings

The Renumeration of British Academics

5

$7 / 00$

The Macroeconomics of Labor and Credit Market Imperfections

Sibling Rivalry in Educational Attainment:

The German Case

Space, Search and Efficiency

2

$8 / 00$

Discretionary Measures of Active Labor Market

Policy: The German Employment Promotion Reform in Perspective

Aggregate-Level Migration Studies as a Tool for 1 Forecasting Future Migration Streams

Intergenerational Influences on the Receipt of 3

Unemployment Insurance in Canada and Sweden

The Post-Unification German Labor Market

4

$8 / 00$

An updated list of IZA Discussion Papers is available on the center's homepage www.iza.org. 